\title{
Morpho-anatomical evaluation of hypoglycaemic medicinal plants
}

Avaliação morfoanatômica de plantas medicinais hipoglicemiantes

\author{
R. S. D. Gondim ${ }^{1}$; I. R. e Silva1; F. F. S. Filho' ${ }^{1}$ T. R. S. A. Luz ${ }^{1}$; T. L. de \\ Castro $^{1}$; M. B. Serra 2 ; W. A. Barroso ${ }^{1,2 *} ;$ C. M. Vilanova ${ }^{1}$ \\ ${ }^{1}$ Pharmacy Department/ Laboratory of Botany, Federal University of Maranhão, 65080-805, São Luis - MA, Brazil. \\ ${ }^{2}$ Emergency Medicine Department / Laboratory of Medical Investigations, University of São Paulo, College of \\ Medicine, 01246-903, São Paulo-SP, Brazil. \\ *wermersonbarroso@usp.br
}

(Recebido em 08 de fevereiro de 2018; aceito em 31 de maio de 2019)

\begin{abstract}
This study aimed to morpho-anatomical characterize leaves of plants with hypoglycemic effect used by the Maracanã community of São Luís-MA. It was selected two vegetal species with lack of morphoanatomical studies, which were Cissus verticillata (L.) Nicolson \& C. E. Jarvis (Vitaceae) and Caesalpinia ferrea Mart. ex. Tul. var. leiostachya Benth (Leguminoceae). The botanic material was collected in the Dom Delgado University City, UFMA. It was realized paradermic and transverse sections free hand with blade support, using astra blue and basic fuchsin as colorants. The laminas were observed and photographed in optic microscopic. Cissus verticillata presented simple and opposite leaves, with membranous consistency, serrated margin, and acute top and cordate base. The mesophyll is dorsiventral composed by palisade and spongy parenchyma. Central rib with presence of reserve parenchyma and angular chollenchyma with some points of ring deposition. Caesalpinia ferrea presented smooth and simple leaves, uniseriate epidermis, curled cuticles and presence of stomata on both sides. Central rib with fundamental parenchyma composed by spherical cells and angular chollenchyma. The reported morphoanatomic characters of $C$. verticillata and $C$. ferrea leaves contribute to the identification and characterization of the quality of these vegetables, improving knowledge verification of plant species authenticity.

Key-words: Hypoglycemic medicinal plants, morpho-anatomical.
\end{abstract}

Este estudo objetivou caracterizar morfoanatomicamente folhas de plantas com efeito hipoglicemiante utilizadas pela população do bairro Maracanã de São Luís-MA. Selecionaram-se duas espécies vegetais com escassez de estudos morfoanatômicos, as quais foram Cissus verticillata (L.) Nicolson \& C. E. Jarvis (Vitaceae) e Caesalpinia ferrea Mart. ex. Tul. var. leiostachya Benth (Leguminoceae). O material botânico foi coletado na Cidade Universitária Dom Delgado, UFMA. Realizaram-se secções paradérmicas e transversais a mão livre com auxílio de lâmina, utilizando-se azul de astra e fucsina básica como corantes. As lâminas foram observadas e fotografadas em microscópio óptico. Cissus verticillata apresentou folhas simples, opostas, com consistência membranácea, margem dentada, ápice agudo e base cordada. O mesofilo é dorsiventral constituído por parênquima paliçádico e lacunoso. Possui nervura central com presença de parênquima de reserva e colênquima angular com alguns pontos de deposição anular. Caesalpinia ferrea apresentou folhas lisas, simples, epiderme unisseriada, cutículas onduladas e presença de estômatos em ambas as faces. Nervura central com parênquima fundamental constituído de células esféricas e colênquima angular. Os caracteres morfoanatômicos das folhas de C. verticillata e C. ferrea relatados contribuem para a identificação e caracterização da qualidade destes vegetais, aprimorando o conhecimento da verificação de autenticidade de espécies vegetais.

Palavras-chave: Plantas medicinais hipoglicemiantes, morfoanatomia.

\section{INTRODUCTION}

Since ancient times, plants are therapeutic resources within the reach of human beings. For millennia, man empirically deepened their knowledge aimed at improving the supply conditions and cure their illnesses, demonstrating a close interrelationship between the use of plants and their evolution, and the knowledge passed down from generation to generation [1].

The interest in plants with hypoglycemic properties has evolved with broad prospects and the first concern relates to quality/authenticity of such plants, in order to avoid tampering, frequent 
falsifications and toxicity. Only through adequate control of the plant drug quality it is possible to ensure the necessary effectiveness and safety of pharmaceuticals, cosmetics and related prepared from herbal drugs. However, not all herbal drugs have established parameters that can contribute to the quality control $[2,3]$.

The authenticity of plant material has usually been evaluated by the botanical identity parameters, by macro and microscopic tests, based on the comparison with an authentic standard sample, pharmacopoeia descriptions and/or specialized literature. Also, by the presence of active and/or characteristic chemical constituents of the species [4].

In the macroscopic evaluation there are reference compendiums to assist the qualified professional in comparisons, based on the characteristic elements identification of species under study. It is essential to define structures that allow differentiation of medicinal plant species from those most frequently found as adulterants [3, 4]. Microscopic evaluation can be based on structures investigation of epidermis (hairs, glands, stomata), parenchyma (fill, xylem, phloem), crystals, vessels, fibers, starch, and among others. In addition, can be performed histochemical reactions [4].

Diabetes Mellitus (DM) is the term used to describe a metabolic disorder with multiple etiologies, characterized by chronic hyperglycemia resulting from disturbances in the metabolism of carbohydrates, lipids and proteins, which are result of impaired secretion and/or action of insulin, or both [5].

In a study conducted by our research group on the ethnobotanical survey of hypoglycemic medicinal plants in Maracanã neighborhood, São Luís - Maranhão, Brazil, were mentioned 27 plant species used with hypoglycemic purpose, and the medicinal plants most cited by respondents were pata-de-vaca (Bauhinia forficata Link), corresponding to $19.3 \%$, vegetable insulin (Cissus verticillata) with $15.3 \%$ and noni (Morinda citrifolia L.) with 9.6\%, still the stick iron (Caesalpinia ferrea) had $3.4 \%$ of citations [6].

In some of plant species already exist in vivo and in vitro studies showing the ability of those present in hypoglycemic action and pharmacobotany characterization studies of their pharmacogens. However, morphological and anatomical data for some of the above species Cissus verticillata (L.) Nicolson \& C. E. and Caesalpinia ferrea Mart. ex. Tul. var. leiostachya Benth are still scarce, although the pharmacological importance of each is well defined.

Cissus verticillata (L.) Nicolson \& C. E. Jarvis is a known popularly as "anil trepador", "uva brava", "cipó-pucá" or "insulina vegetal" in Brazil [7]. Its leaves are used externally against rheumatism, abscesses and infusions of leaves and stems are used in muscle inflammation, hypotension and activating the blood circulation. The species in reference has been widely used by the population for diabetes treatment, and it is known as "vegetable insulin", giving reason for botanical studies, chemical and pharmacological in Brazil and abroad [7, 8, 9, 10, 11].

Caesalpinia ferrea Mart. ex. Tul. var. leiostachya Benth, popularly known as "pau-ferro" in Brazil, it is a tree 10-20 m tall, straight trunks, dark and irregular white spots, very used for afforestation of parks and squares. Its fruits are pods of black-red color, fleshy and indehiscent [12]. The fruits has antidiarrheal, anticatarral and healing properties and the roots are antipyretic [13]. It has been used for diabetes treatment [14]. Other therapeutic properties of this plant include anti-inflammatory, antiulcer [15, 16], analgesic [17], anticancer [18], antibacterial [19] and antihypertensive [20]. Given its importance etnomedicinal, the Ministry of Health in Brazil included this species in the National List of Medicinal Plants important for the Unified Health System [20].

Based on the above and considering the leaves of $C$. verticillata (Insulina vegetal) and $C$. ferrea (Pau ferro) has abundant materials referenced by its various properties, including hypoglycemic, it demonstrated the necessity of conducting a morphoanatomic study their leaves, in order to increase knowledge on these plant species used by the Maracanã neighborhood population, São Luís, Maranhão, Brazil. 


\section{BOTANICAL IDENTIFICATION, MORPHOLOGICAL AND ANATOMICAL STUDIES}

The Cissus verticillata and Caesalpinia ferrea species were selected by the lack of morphoanatomics studies in these species. The samples were collected and used for botanical identification, morphological and anatomical studies. The species were collected in the Horto Medicinal Berta Langes de Morretes of Dom Delgado University City, Federal University of Maranhão (UFMA) and identified in the Herbarium Atticus Seabra (SAH) from the same institution. The herbarium specimens are deposited in SAH under number 00834 for $C$. ferrea and number 01251 for $C$. verticillata. synonyms in the botanical nomenclature of each species were surveyed in Tropicos site [21], linked to the Missouri Botanical Garden.

For external morphological study, four leaves of each species were observed as to phyllotaxy, composition, color, consistency, the leaf surface, size, shape, apex, base, margin and veining system [22]. For the analysis of the internal organization of the adult leaf tissues were carried out cross-sections of the middle region of the leaf, including the midrib, and paradermic sections of both sides obtained a free hand with the aid of cutting blades. The sections were clarified with sodium hypochlorite solution $50 \%$, washed with distilled water, stained with astra blue and basic fuchsin, both at $0.5 \%$. Then mounted between slide and cover slip with $50 \%$ glycerin. Descriptions and photomicrographs were taken in an optical microscope Olympus CH30 coupled to digital camera Samsung SDC - 415.

\section{RESULTS AND DISCUSSION}

The leaves of Cissus verticillata are simple, opposite, with membranous consistency, ovate shape limbo, toothed margin, acute apex and cordate base (Figure 1A). These macroscopic characteristics corroborate the studies by Lorenzi \& Matos (2002) [23] and Souza \& Lorenzi (2005) [24]. Also, showed simple tendril with cylindrical format, and a green color (Figure 1B). This structure is the result of total or partial modification of leaf, stem or root. These tendrils allow launch and assisting in the plant support [25].

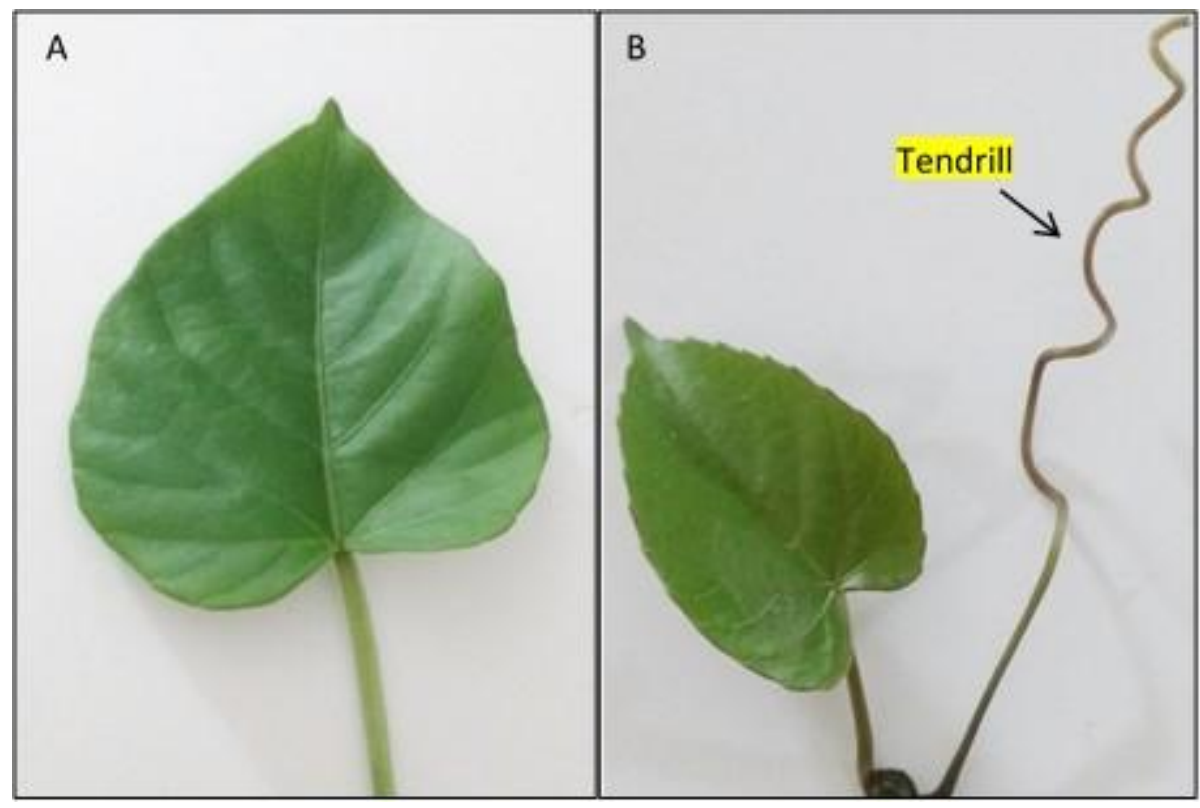

Figure 1: Cissus verticillata (Vitaceae). A: Leaf Blade, B: General view of the leaf tendril branch.

In cross section, the species $C$. verticillata showed the leaf blade with uniseriate epidermis, and presence of cuticles and absence of trichomes (Figure 2A). In morphoanatomic study of some species of Cissus, the presence of trichomes was evident [26]. The cuticles reduce water loss through transpiration, present an additional barrier when in contact with the dirty air inlet 
and pathogens into the interior of leaves, representing a major adaptation developed for terrestrial plants [27, 28].

In the central rib $C$. verticillata we observed the presence of reservation parenchyma (aerenchyma) and angular collenchyma with some points of annular deposition (Figure 2A). According Seago et al. (2005) [29], the aerenchyma formation occurs by expanding intercellular spaces of gaps, division and cell expansion or, less often, by destroying or lysing the cell. The chollenchyma of void type develops from the angle, the latter being the most common [40].

The mesophyll is dorsiventral, which consists of a palisade layer, followed by four to five layers of spongy parenchyma (Figure 2B). In the middle of parenchyma occurs idioblasts (Figure 2B), in presence of calcium oxalate crystals in the form of drusen or raphides. According to Fahn (1990) [30], idioblasts can secrete various substances, being tannins, mucilages, oils, essences, and among others. The identification of idioblasts as local secretion of these compounds, responsible for potential activity of the plant, is very important for the future of bioprospecting research on this species.

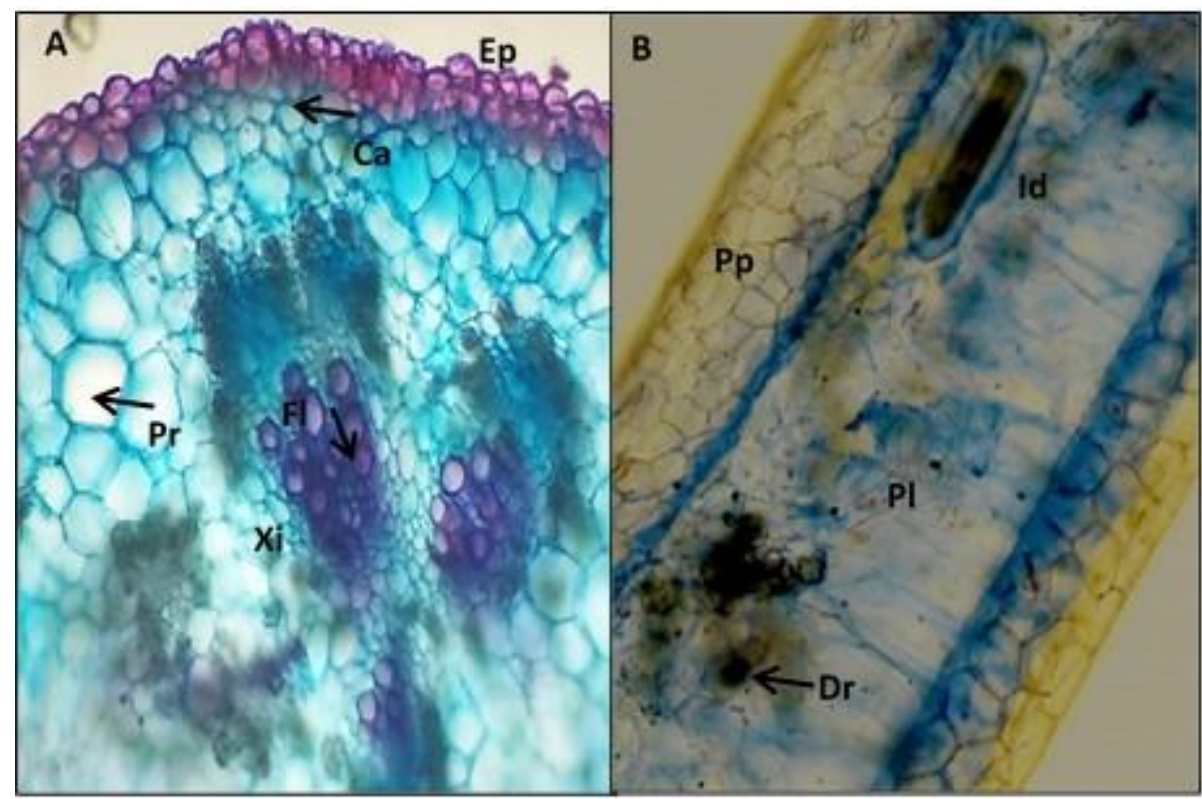

Figure 2: Cross section of leaf of Cissus verticillata. A: Central Vein B: Mesophyll. Ca: Angular Chollenchyma; Dr: Druze; Ep: Epidermis; Fl: Phloem; Id: idioblast with raphides; Pr: Reserve Parenchyma (aerenchyma); Pp: Palisade Parenchyma; Pl: Spongy Parenchyma; Xi: Xylem.

The leaves of $C$. verticillata is amphistomatic with stomata of anomocytic type (Figure 3). The epidermis of abaxial surface (Figure 3A) has a higher concentration of stomata in relation to adaxial (Figure 3B). In the study by Greulach (1973) [31], it was reported that amphistomatic leaves usually have higher amount of stomata in the epidermis of abaxial face, but in some species the stomata appear in the same proportions. However, it is noteworthy that such a characteristic is greatly influenced by environmental issues, where plants grow in full sunlight have more stomata than those growing in the shade and the presence of the highest concentration in the abaxial face can be a way to avoid losing excessive water [32], and increasing the photosynthetic efficiency [28]. 


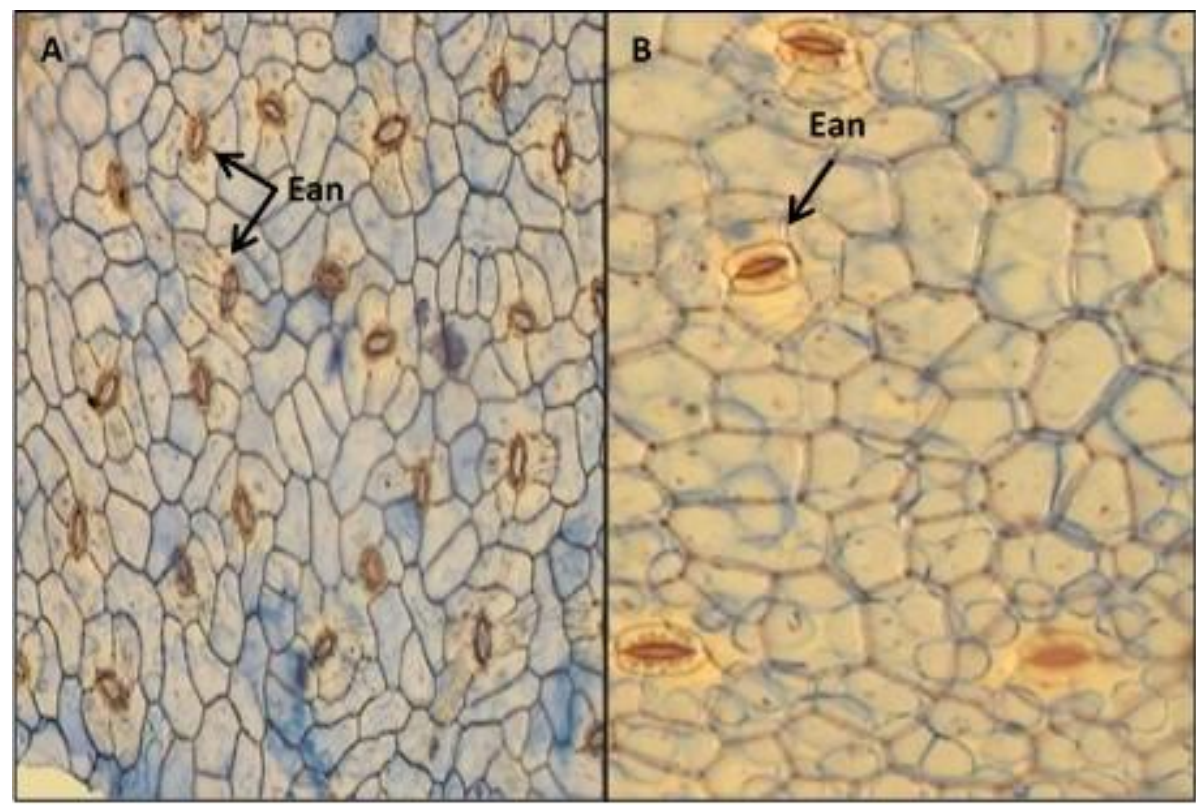

Figure 3: Cross section of the leaves of Cissus verticillata. A: abaxial face, B: adaxial side. Ean: anomocytic stomata.

The leaves of Caesalpinia ferrea are simple, smooth, opposite or alternate, opaque, and discolores. Have symmetrical based asymmetric, rounded to cuneate and rounded apex, with entire flat edge (Figure 4). They presented uniseriate epidermis, with cuticles in wavy aspect. These aspects were also observed in studies of Bortoluzzi et al. (2007) [33].

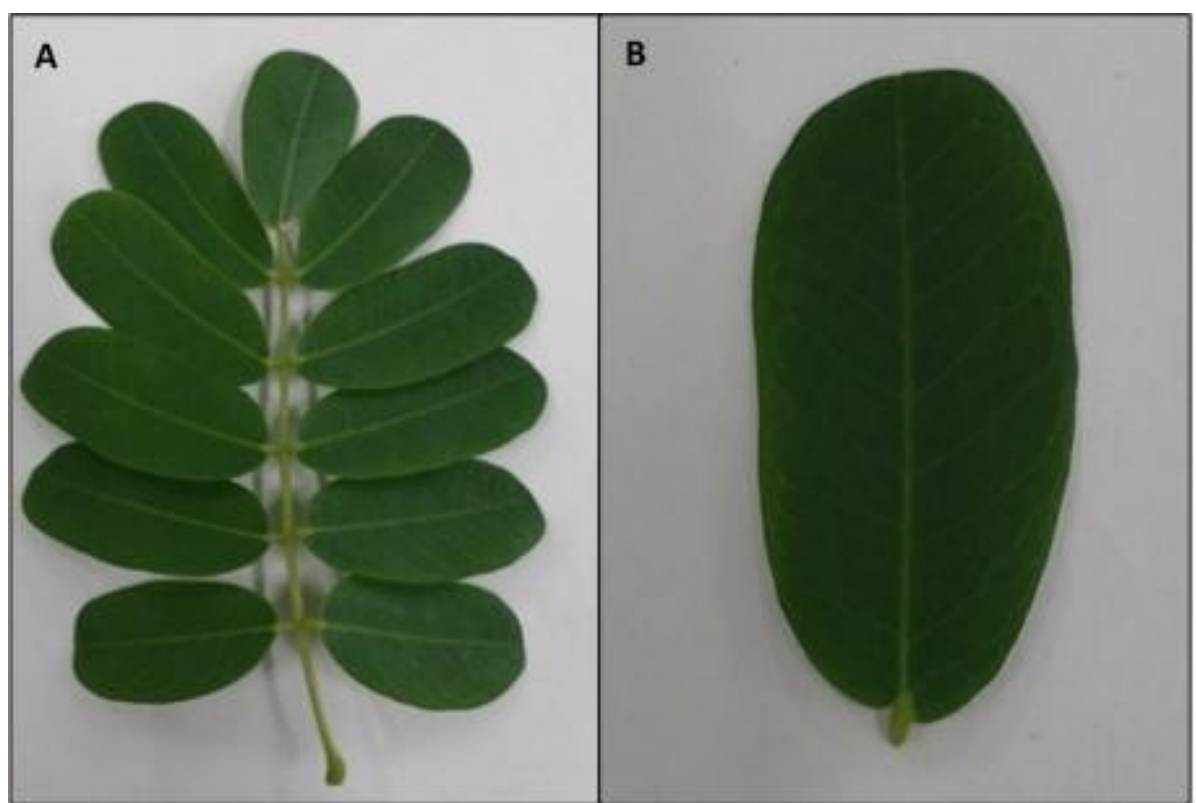

Figure 4: Caesalpinia ferrea (Leguminosae). A: general appearance of the branches, B: leaf blade.

In transverse sections, the $C$. ferrea leaves have basic parenchyma or fill cells with spherical and angular collenchyma (Figure 5A). There is the presence of trichomes (Figure 5B) which are common in the genus, and the species can present simple trichomes, glandular, peltate or branched [34]. The trichomes form, usually a dense covering, may serve as a mechanical barrier against various external factors, such as herbivores and pathogens, ultraviolet radiation, extreme heat and excessive water loss. While the glandular trichomes are involved with chemical protection by release of lipophilic substances [35]. 


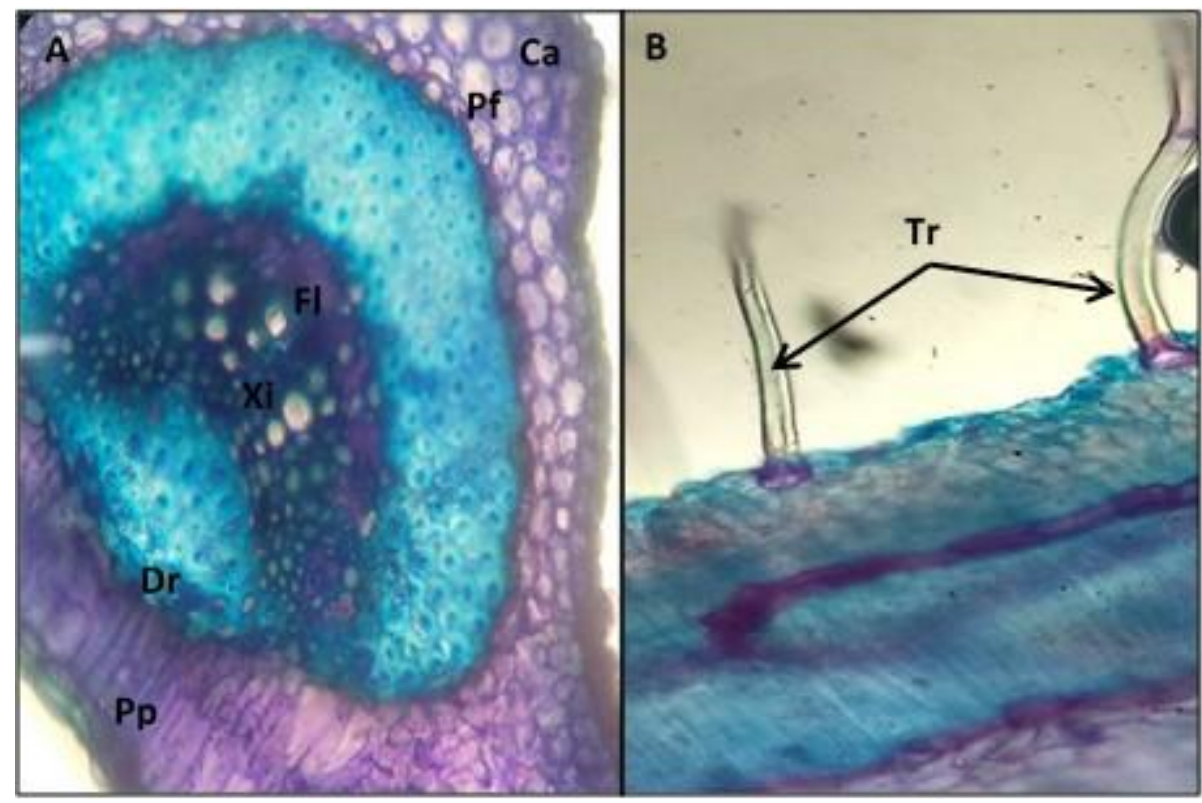

Figure 5: Cross section of leaf of Caesalpinia ferrea. A: Central rib B: mesophyll. Ca: angular chollenchyma; Dr: Druze; Ep: epidermis; Fl: phloem; Mp: fundamental parenchyma with spherical cells; Pp: palisade; Pl: spongy parenchyma; Tr: trichomes; Xi: xylem.

The mesophyll of $C$. ferrea is dorsiventral, compact, has a typical palisade parenchyma located along the adaxial epidermis (Figure 6). The parenchymal cells facing the abaxial epidermis with small intercellular spaces are similar to the palisade and also have a sclerenchymatous sheath. According to Metcalfe \& Chalk (1950) [36] and Watson (1981) [37], the mesophyll in Caesalpinioideae is generally dorsiventral, proven characteristic by Cuttis et al. (1996) [38]. The palisade parenchyma allows better penetration of light in chloroplasts. Thus, it is believed that leaves exposed to sun, with the presence of palisade parenchyma well developed, has an efficient structure in terms of photosynthesis [39]. Another environmental factor that may relate to structural changes in the mesophyll is the availability of water. Plants of dry environment (xerophytes) have palisade parenchyma more developed than spongy. Already hydromorphic leaves appear as large common character intercellular spaces and mesophilic feature combinations of these two environments [40].

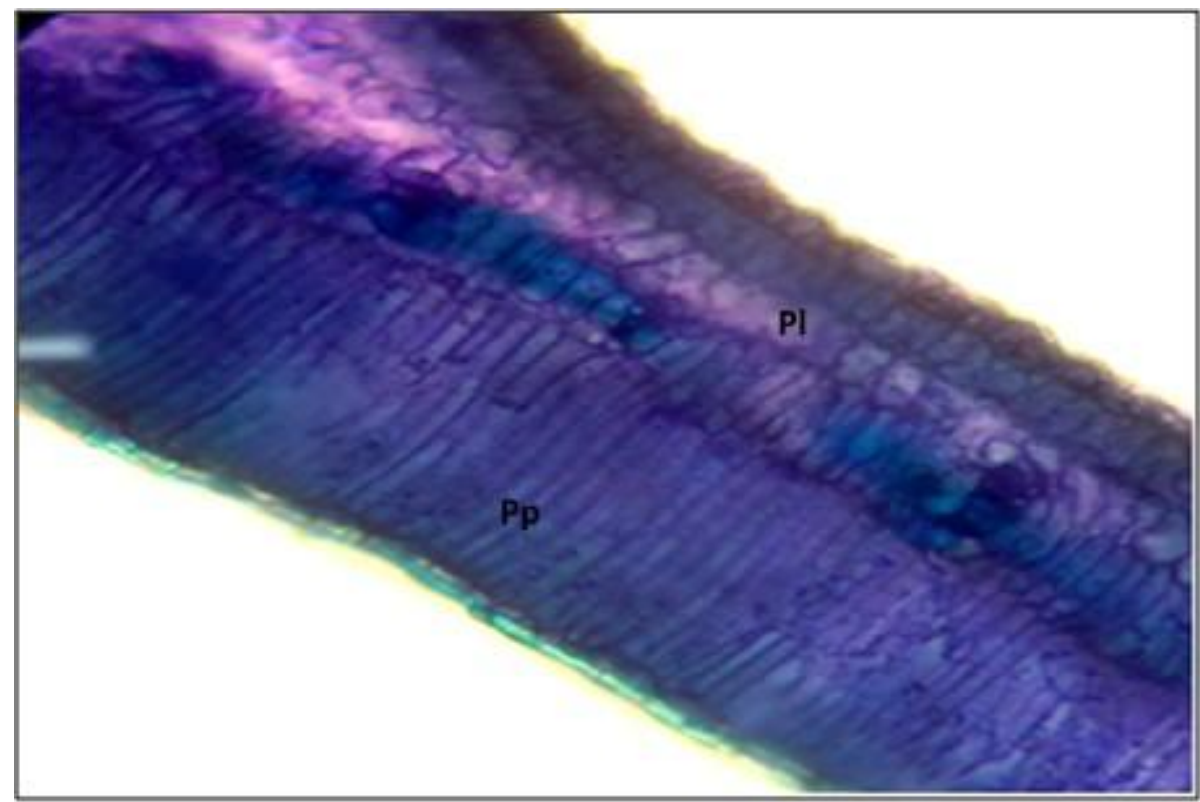

Figure 6: Cross section of mesophyll region of Caesalpinia ferrea. Pp: palisade parenchyma; Pl: spongy parenchyma. 
The paradermic cut of $C$. ferrea indicated the stomata presence of paracitic type (Figure 7) on leaves both sides and the abaxial surface (Figure 7A) is displayed in a larger quantity, classified as amphistomatic. The paracytic stomata of $C$. ferrea are typical of his family [41]. In the most of Caesalpinioideae, the stomata are mostly found in abaxial face, and in the adaxial face are scarce and restricted to areas adjacent to ribs $[36,37]$.

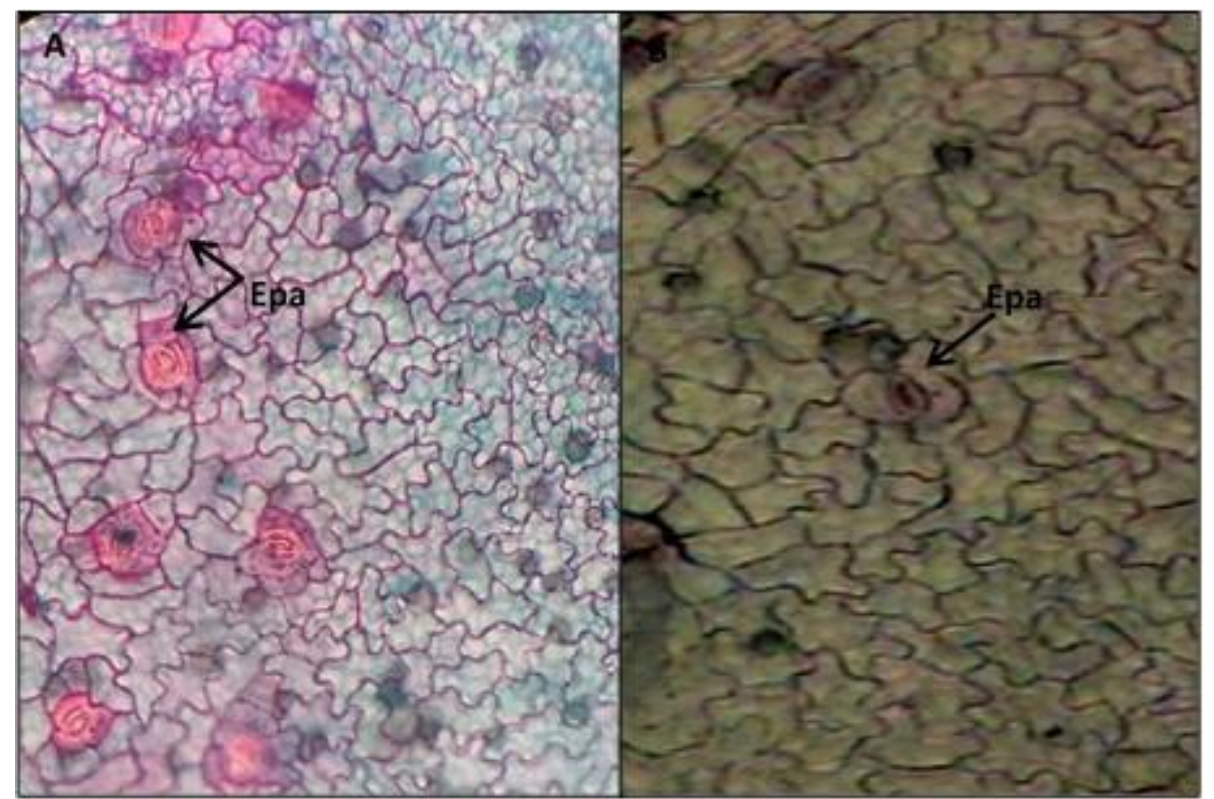

Figure 7: Cross section of the leaves of Caesalpinia ferrea. A: abaxial side, B: adaxial side. Epa: paracytic stomata.

\section{CONCLUSION}

Morphological and anatomical features of the leaves of C. verticillata and C. ferrea reported contribute to the identification and characterization of vegetables quality, improving the knowledge of these species in the area of pharmacobotany. Become necessary studies to ensure the quality of plant and herbal drug, as well as and the application of methods to assess the authenticity, since macroscopic and microscopic characteristics are taken into account as authenticity parameter. Given the above, the importance of knowledge pharmacobotanic is associated with three factors: authenticity check of plant species; elaboration of monographs for incorporation species on official books, such as Pharmacopoeias, and quality control of commercial samples.

\section{ACKNOWLEDGMENTS}

The authors thank to Fundação de Amparo à Pesquisa e ao Desenvolvimento Científico e Tecnológico do Estado de Maranhão (FAPEMA) and Universidade Federal do Maranhão (UFMA) for providing financial support.

\section{REFERENCES}

1. Santos CAP. Extratos vegetais em cosméticos. Cosmet Toilet. 2006;18:96-103.

2. Baby AR, Maciel COM, Salgado-Santos IMN, Dias TCS, Kaneko TM, Consiglieri VO, Velasco MVR. Uso de extratos de plantas em produtos cosméticos. Cosmet Toilet. 2005;17:78-82.

3. Garcia ES, Silva ACP, Gilbert B, Correa CVB, Cavalheiro MVS, Santos RR; Tomassine T. Fitoterápicos; 2016. [Acesso em 04 fev 2016]. Disponível em: www.bdt.fat.org.br.

4. Farias RS. Avaliação da qualidade de matérias-primas vegetais. 6a . Ed. In Simões et al. 2010. Capítulo 12, Farmacognosia: da planta ao medicamento; p. 263-288. 
5. Sociedade Portuguesa de Diabetologia (SPD). Classificação de Diabetes Mellitus; 2016. [Acesso em 04/02/2016]. Disponível em: http://www.spd.pt/index.php/grupos-de-estudo-mainmenu30/classificao-dadiabetes-mellitus-mainmenu-175

6. Gomes PRM, Firmo WCAF, Vilanova CM. Estudo etnobotânico de plantas medicinais hipoglicemiantes no bairro Maracanã no município de São Luís, Maranhão, Brasil. Sci Plena. 2014;10(9).

7. Agra MDF, Freitas PFD, Barbosa-Filho JM. Synopsis of the plants known as medicinal and poisonous in Northeast of Brazil. Rev Bras Farmacog. 2007;17(1):114-140. doi:10.1590/S0102695X2007000100021.

8. Mori T, Nishika WAY, Takata Y, Kashiuchi N, Ishihara N. Effect of insulina leaf extract on development of diabetes: comparison between normal, streptozotocininduced diabetic rats and hereditary diabetic mice. J Jpn Soc Nut Food Sci. 2001;54:197-203.

9. Beltrame FL, Sartoretto JL, Bazotte, RB, Cuman, RN, Cortez, D. Estudo fitoquímico e avaliação do potencial antidiabético do Cissus sicyoides L. (Vitaceae). Quim Nov. 2001;24:783-785. doi:10.1590/S0100-40422001000600014

10. Pepato MT, Baviera AM, Vendramini RC, Perez MPMS, Kettelhutt IC, Brunetti IL. Cissus sicyoides (princess vine) in the long-term treatment of streptozotocin-diabetic rats. Biot Appl Bioch. 2003; 37:15-20. doi:10.1042/BA20020065.

11. Barbosa-Filho JM, Vasconcelos THC, Alencar, AA, Batista LM, Oliveira RAG, Guedes DN, Falcão HS, Moura MD, Diniz MFFM, Modesto-Filho, J. Plants and their active constituints from South, Central and North América with hypoglicemic activity. Rev Bras Farmacogn. 2005;15:392-413. doi.org/10.1590/S0102-695X2005000400021.

12. Lorenzi H. Árvores brasileiras: manual de identificação e cultivo de plantas arbóreas nativas do Brasil. Nova Odessa: Plantarum, 2000.

13. Maia GN. Caatinga: árvores e arbustos e suas utilidades. São Paulo: D\&Z Computação Gráfica, Leitura \& Arte; 2004. 413 p.

14. Araújo TAS, Alencar NL, Amorim ELC. A new approach to study medicinal plants with tannins and flavonoids contents from the local knowledge. J Ethnopharmacol. 2008;120:72-80. doi.org/10.1016/j.jep.2008.07.032

15. Bacchi, EM, Sertié, JJA. Antiulcer action of Styrax camporum and Caesalpinia ferrea in rats. Pl Med. 1994;60:118-120. doi:10.1055/s-2006-959430

16.Bacchi EM, Sertié JAA, Villa N, Katz H. Anti-ulceraction and toxicity of Styrax camporum and Caesalpinia ferrea. Pl Med. 1995;61:204-207. doi:10.1055/s-2006-958056

17. Carvalho JCT, Teixeira JRM, Souza PJC, Bastos JK, Santos-Filho D, Sarti, SJ. Preliminary studies of analgesic and anti-inflammatory properties of Caesalpinia ferrea crude extract. J Ethnopharmacol. 1996; 53:175-178. doi: 10.1016/0378-8741(96)01441-9

18. Sampaio, FC, Pereira, MSV, Dias CS, Costa VCO, Conde NCO, Buzalaf MAR. In vitro antimicrobial activity of Caesalpinia ferrea Martius fruits against oral pathogens. J Ethnopharmacol. 2009;141:289294. doi:10.1016/j.jep.2009.04.034

19. Menezes IAC, Moreira IJA, Carvalho AA, Antoniolli AR, Santos, MRV. Cardiovascular effects of the aqueous extract from Caesalpinia ferrea: involvement of ATP-sensitive potassium channels. J Cardiovasc. Pharm. 2007;47:41-47. doi: 10.1016/j.vph.2007.03.005

20. BRASIL. Ministério da Saúde. RENISUS - Relação Nacional de Plantas Medicinais de Interesse ao SUS. Espécies vegetais. DAF/SCTIE/MS - RENISUS - fev/2009 [portaria na internet]. [Acesso em 02/02/16]. Disponível em: http://portal.saude.gov.br/portal/arquivos/pdf/RENISUS.pdf

21. Trópicos. [Acesso em 28/01/2018]. Disponível em: http://www.tropicos.org/

22. Vidal WN, Vidal MRR. Botânica: organografia. Viçosa: Imprensa Universitária UFV; 2007. 124 p.

23. Lorenzi H, Matos, AFJ. Plantas medicinais no Brasil: nativas e exóticas. São Paulo: Plantarum; 2002. $544 \mathrm{p}$.

24. Souza VC, Lorenzi H. Botânica sistemática: guia ilustrado para identificação das famílias de Angiospermas da flora brasileira, baseado em APG II. São Paulo. Nova Odessa: Instituto Plantarum; 2005. $640 \mathrm{p}$.

25. Ribeiro JELS, Hopikins MJG, Vincentini A. Flora da reserva Ducke: Guia de identificação das plantas vasculares de uma floresta de terra firme na Amazônia Central. Manaus: INPA; 1999. $816 \mathrm{p}$.

26. Oliveira ABD, Mendonça MSD, Azevedo AA, Meira RM. Anatomy and histochemistry of the vegetative organs of Cissus verticillata: a native medicinal plant of the Brazilian Amazon. Rev Bras Farmacogn. 2012;22(6):1201-1211. doi.org/10.1590/S0102-695X2012005000092

27. Dickison WC. Integrative plant anatomy. London: Academic Press; 2000. 535 p.

28. Taiz L, Zeiger E. Fisiologia do estresse. Fisiologia vegetal. 2004; p. 738-772. 
29. Seago JL Jr, Marsh LC, Stevens KJ, Soukup A, Votrubová O, Enstone DE. A re-examination of the root cortex in wetland flowering plants with respect to aerenchyma. Ann Bot. 2005 Sep;96(4):565-79. doi:10.1093/aob/mci211

30. Fahn, A. Plant anatomy. Oxford: Pergamon Press; 1990.600 p.

31. Greulach VA. Plant structure and function. New York: The Macmillan Company; 1973. 575 p.

32. Willmer CM. Los estomas. Buenos Aires: Mosaico. 1983. 192 p.

33.Bortoluzzi RLC, Miotto STS, Biondo E, Schiffino-Wittmann MT. Estudos morfológicos, citotaxonômicos e moleculares no grupo Caesalpinia I. sensu amplo: Caesalpinia, hoffmanseggia e Pomaria no sul da América do Sul, 2007.

34. Simpson BB, Lewis GP. New combinations in Pomaria (Caesalpinioideae: Leguminosae). Kew Bull. 2003;58:175. doi: $10.2307 / 4119360$

35. Valkama E, Salminen JP, Koricheva J, Pihlaja K. Comparative analysis of leaves trichome structure and composition of epicuticular flavonoids in Finnish Birch species. Ann Bot. 2003;91(6):643- 655. doi:10.1093/aob/mcg070

36. Metcalfe CR, Chalk L. Anatomy of the Dicotyledons. Clarendon Press: Oxford. 1950; 1:243-245.

37. Watson L. An automated system of generic descriptions for Caesalpinioideae, and its application to classification and Key-making. In: Polhill, R.M. \& Raven, P.H. (ed.). Advances in legume systematics. Roy Bot Gard. 1981;1:65-80.

38. Lersten RN, Curtis DJ. Leaf anatomy in Caesalpinia and Hoffmannseggia (Leguminosae, Caesalpinioideae) with emphasis on secretory structures. Plant Syst Evol. 1994;192:231-255. doi: 10.1007/BF00986254

39. Mendes MM, Gazarini LC, Rodrigues ML. Acclimation of Myrtus communis to contrasting Mediterranean light environments-effects on structure and chemical composition of foliage and plant water relations. Environ. Exp Bot. 2001;45:165-178.

40. Esau K. Secretory tissues in plants. London: Academic Press. 1997; 302 p.

41. Metcalfe CR, Chalk L. Anatomy of the dicotyledons. Oxford: Clarendon Press; 1957. 557 p. 